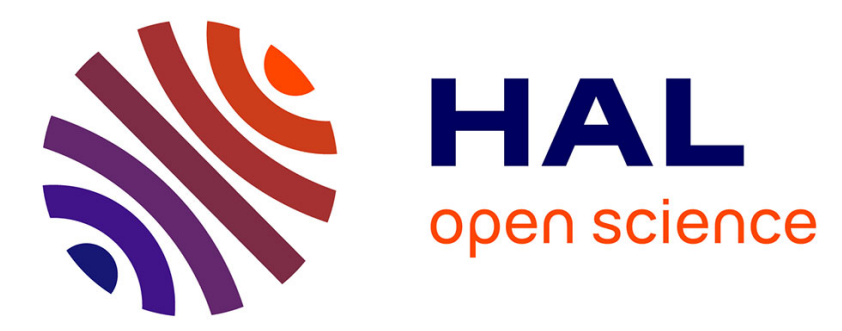

\title{
Intercomparaison of experimental and numerical simulation results on mechanical behaviour of corroded beams
}

\author{
Ilie Petre-Lazar, Olivier Poupard, Claude Brunet
}

\section{- To cite this version:}

Ilie Petre-Lazar, Olivier Poupard, Claude Brunet. Intercomparaison of experimental and numerical simulation results on mechanical behaviour of corroded beams. Revue Européenne de Génie Civil, 2007, Benchmark des poutres de La Rance, 11 (1-2), pp.9-33. 10.1080/17747120.2007.9692920 . cea02355768

\section{HAL Id: cea-02355768 https://hal-cea.archives-ouvertes.fr/cea-02355768}

Submitted on 2 Dec 2019

HAL is a multi-disciplinary open access archive for the deposit and dissemination of scientific research documents, whether they are published or not. The documents may come from teaching and research institutions in France or abroad, or from public or private research centers.
L'archive ouverte pluridisciplinaire HAL, est destinée au dépôt et à la diffusion de documents scientifiques de niveau recherche, publiés ou non, émanant des établissements d'enseignement et de recherche français ou étrangers, des laboratoires publics ou privés. 


\title{
Benchmark des poutres de La Rance
}

\section{Inter-comparison of experimental and numerical simulation results on mechanical behaviour of corroded beams}

\author{
Ilie Petre-Lazar* — Olivier Poupard** _ Claude Brunet*** \\ * EDF R\&D, Les Renardières, Route de Sens - Ecuelles, 77250 Moret sur Loing \\ Cedex, France. \\ ** Laboratoire Pierre Sue, CNRS/CEA Saclay, bât. 637, 91191 Gif-sur-Yvette, \\ France. \\ *** EDF SEPTEN/GC 12-14 ,Avenue Dutrievoz, 69628 Villeurbanne cedex \\ email adress : claude.brunet@edf.fr
}

RÉSUMÉ. Le programme de recherche du Réseau Génie Civil et Urbain «Benchmark des Poutres de la Rance " s'inscrit dans la thématique de réévaluation des marges de sécurité et le suivi des ouvrages en béton armé et précontraint en environnement agressif. Il implique de nombreux partenaires académiques et industriels : CEA, EDF R\&D, CEBTP (Centre d'Expertise du Bâtiment et des Travaux Publics), LCPC (Laboratoire Central des Ponts et Chaussées, Paris), LMDC (Laboratoire Matériaux et Durabilité des Constructions, Toulouse), LMT (Laboratoire de Mécanique et Technologie, Cachan), LML (Laboratoire de Mécanique de Lille), GéM (Institut de Recherche en Génie Civil et Mécanique, Nantes), OXAND (Société anonyme) et IETcc (Instituto de Ciencias de la Construccion Eduardo Torroja, Espagne). Ces équipes travaillent sur l'endommagement par corrosion des armatures du béton armé et précontraint. Ce papier présente une analyse critique comparative des résultats expérimentaux (essai de traction directe et essai de flexion 4 points) et des résultats des simulations numériques menées par les différents partenaires.

ABSTRACT. The "benchmark des poutres de la Rance" research project contributes to the study of safety margin re-assessment and to the monitoring of prestressed and reinforced concrete structures in aggressive environment. Several academic and industrial partners are involved in this project: CEA, EDF R\&D, CEBTP, LCPC, LMDC, LMT, LML, GéM, OXAND and IETCC. These teams are involved in researches and studies related to the mechanical effect of corrosion and the damage in civil engineering concrete structures. The paper presents a critical comparison of the experimental results and the numerical simulations (tensile and 4-points bending tests) performed by the different project partners.

MOTS-CLÉS : Benchmark, Béton précontraint, Béton armé, Corrosion, Essai de traction, Essai de flexion 4-points, Simulations numériques

KEYWORDS: Benchmark, Prestressed concrete, Reinforced concrete, Corrosion, Tensile test, 4points bending tests, Numerical simulations

Revue. Volume $\mathrm{X}-\mathrm{n}^{\circ} \mathrm{x} /$ année, pages 1 à $\mathrm{X}$ 


\section{Introduction}

Rebar corrosion is a major cause of damage of the civil engineering structures and is recognized as a key issue for ageing concrete structures (Tuutti, 1982). For example, according to IQOA database in 1997, about 28\% of bridges in France among bridges in government charge have been exposed to corrosion degradation. Initially, reinforcing steel embedded in concrete is naturally protected from corrosion by the high alkalinity of its interstitial solution (Tuutti, 1982) (Neville, 1995). However, this passive film can be destroyed by chlorides ingress or by carbonation. Whatever the cause, corrosion of steel can lead to cracking of reinforced concrete and subsequent loss of the load-carrying capacity. Considerable resources are spent to repair and rehabilitate deteriorating concrete structures.

The approaches usually used for designing or rehabilitating civil engineering structures are based on the estimation of the corrosion initiation times as a function of the materials properties. However, in most cases, this initiation time is exceeded, rebar is already corroded, and it is essential to know the influence of corrosion on the mechanical behaviour .

This knowledge will contribute to determine the residual safety margin of reinforced-concrete structures with regards to the total failure and so enhance the safety of such structures. Previous studies have been only focused on the mechanical behaviour and the actual safety of concrete structures (Ghavamian, 2003). Other studies have addressed the development of models for the influence of corrosion on the load carrying capacity of prestressed / reinforced concrete structures (Rodriguez, 1997) (Castel, 2000) (Dekoster, 2003). Now, these developments require to be benchmarked and validated on existing concrete structures.

The French research project "Benchmark des poutres de la Rance" contributes to this item through a study of 20 reinforced concrete beams exposed for 40 years in a marine environment. The objective of this project is to improve the knowledge of the uncertainties due to numerical simulations and measurements: (i) by quantifying the differences between the modelling and the experimental results, (ii) by evaluating the loss of safety margins of reinforced concrete structures exposed to corrosion, (iii) by improving knowledge on the main corrosion parameters influencing the mechanical behaviour (reduction of the rebar section and/or reduction of the steel-concrete bond and/or ductility) and (iv) by promoting the validation of some future mechanical models based on the experimental database obtained during this project.

This study is labelled by RGCU (Urban and Civil Engineering Network) This research and technological innovation network is promoting researches which involved public and industrial partners in the scope of the maintenance of civil infrastructures. 


\section{Presentation of the Benchmark}

This project is based on a long-term experimental program started in 1962 by the "Union Technique Interprofessionnelle des Fédérations Nationales du Bâtiment et des Travaux Publics”. Initially 40 prestressed concrete beams were cast and stored in marine environment (Rance dam) (Figure 1). In 1976, these beams were moved to the Sainte Anne du Portzic harbour (IFREMER, Brest), in a tidal zone. Within the project framework, 10 prestressed beams were used for assessing the mechanical behaviour after a 40 years exposure period in marine environment.

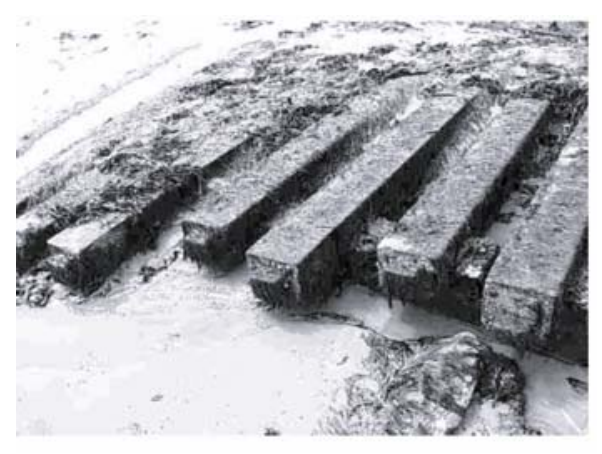

Figure 1. Prestressed beams during long-term exposure in marine environment

The benchmark is divided into three steps:

1. an experimental program has been designed to evaluate the corrosion influence on the mechanical behaviour. Two types of mechanical tests have been defined: (i) direct tensile tests (ii) 4-point bending tests. The results of mechanical tests were kept secret during the numerical simulations even though the distribution of corrosion has been known.

2. various partners have computed the mechanical behaviour of the beams under tensile and flexural tests.

3. experimental results and numerical simulations have been compared and analysed. Conclusions are focused on the pertinence and reliability of the tested mechanical models.

It must be noticed that these calculations have been performed with:

- $\quad$ corroded configuration considering real corrosion profiles of beams (to be compared to experimental measurements)

- $\quad$ intact configuration, by considering no corrosion, as a reference solution to analyse the reduction of ultimate load. 
The influence of corrosion on mechanical behaviour may be estimated by comparing the simulations results between these configurations.

\section{Description of the beams}

The beams dimensions are $2500 \times 200 \times 200 \mathrm{~mm}$. The ends (on $250 \mathrm{~mm}$ ) are protected by a bituminous coating. Each beam is identified with three numbers: the first one corresponds to the lay-out configuration (see Figure 2 for more details), the second one to the aggregate grading (continuous or discontinuous) and the last one to the cement content (300 or $400 \mathrm{~kg} / \mathrm{m}^{3}$ of cement). Table 1 illustrates the composition of each tested concrete, the porosity values estimated by MIP and the water absorption. Fig. 2 presents schematic views of the details of the cross-sections of each beam. They are reinforced with passive plain carbon steel bars $(\varnothing 6 \mathrm{~mm})$ and 10 stirrups ( $\varnothing 6 \mathrm{~mm}$ ) spaced at about $250 \mathrm{~mm}$. Two depth of concrete cover are used for the passive reinforcing steels : 16 or $41 \mathrm{~mm}$ depending on the configuration. Details of the reinforcement arrangement were observed by using Ferroscan ${ }^{\circledR}$ electromagnetic scanning system.

Table 1. Concrete mixture proportions.

\begin{tabular}{|c|c|c|c|c|c|c|c|c|}
\hline \multirow{2}{*}{ Concrete } & \multirow{2}{*}{$\begin{array}{c}\text { Total } \\
\text { water } \\
\text { (l) }\end{array}$} & \multirow{2}{*}{$\begin{array}{l}\text { Cement } \\
\text { kg.m }\end{array}$} & \multicolumn{3}{|c|}{$\begin{array}{c}\text { Aggregates grading } \\
\left(\mathrm{kg} / \mathrm{m}^{3}\right)\end{array}$} & \multirow{2}{*}{$w / c$} & \multirow{2}{*}{$\begin{array}{c}\text { Porosity } \\
\text { by MIP } \\
(\%)^{1}\end{array}$} & \multirow{2}{*}{$\begin{array}{c}\text { Porosity } \\
\text { by water } \\
\text { absorpt. } \\
(\%)\end{array}$} \\
\hline & & & $\begin{array}{l}\text { Sand } \\
0 / 5\end{array}$ & $\begin{array}{c}\text { Gravel } \\
10 / 25\end{array}$ & $\begin{array}{c}\text { Gravel } \\
5 / 15\end{array}$ & & & \\
\hline 1.1 & 210 & 300 & 800 & 930 & 320 & 0.7 & 15.3 & 15.7 \\
\hline 1.2 & 210 & 400 & 550 & 930 & 290 & 0.525 & 13.1 & 13.4 \\
\hline 2.1 & 220 & 300 & 500 & 1350 & I & 0.73 & 15.7 & 16.7 \\
\hline 2.2 . & 250 & 400 & 450 & 1350 & 1 & 0.625 & 14.5 & 16.4 \\
\hline
\end{tabular}

The concrete is prestressed with wires, $7 \mathrm{~mm}$ in diameter, embedded in a plastic sheath, $12 \mathrm{~mm}$ in diameter, and anchored at the beam ends. For beams of type 1 and 2 , prestress wires are centered along the axis of the beam whereas they are in the lower part of the beam for the beams of type 4, 6 and 9 as indicated on Fig. 2. So, in these cases, the concrete prestress produces a cracking pattern similar to the pattern of a structure during a long-term exposure. Table 2 presents the initial longitudinal stresses within the concrete (respectively in the upper and lower parts of the beam) due to presence of the prestress wires. 


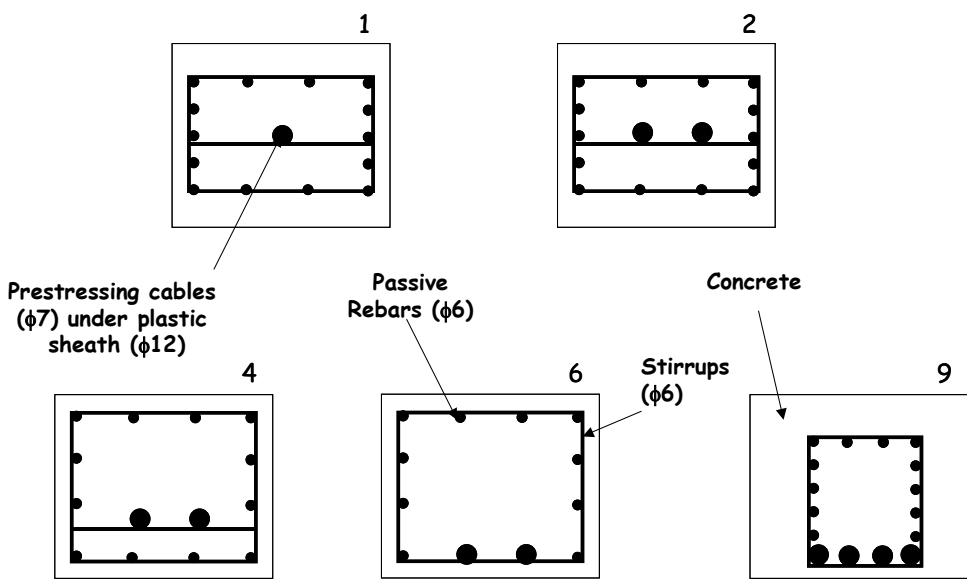

Figure 2: Schematic view of the cross section of each types of beam.

Table 2: Stresses within concrete in upper and lower areas of the beams.

\begin{tabular}{ccc}
\hline \multirow{2}{*}{$\begin{array}{c}\text { Configuratio } \\
\text { n }\end{array}$} & \multicolumn{2}{c}{$\begin{array}{c}\text { Stress in concrete } \\
\text { (in MPa) }\end{array}$} \\
\cline { 2 - 3 } & Upper part & Lower part \\
\hline Type 1 & $1.66-1.74$ & $0.73-0.77$ \\
Type 2 & $2.63-2.95$ & $1.67-1.99$ \\
Type 4 & $-0.73--0.76$ & $5.46-5.77$ \\
Type 6 & $-2.19--2.39$ & $6.77-7.38$ \\
Type 9 & $-5.07--5.30$ & $14.75-15.35$ \\
\hline
\end{tabular}

Traction are negative, compression are positive

\section{Mechanical tests}

The 4-point bending test is a usual test and is largely used to simulate the mechanical behaviour of a beam in flexion. Mechanical tests used are described in (Vié, 2006). We can notice that in the 4-point bending test two configurations have been tested (a) in PC configuration (Prestressed Concrete) (b) in RC configuration (Reinforced Concrete) (figure 3). In the RC configuration the tendons are located in the compressed concrete zone. This approach allows to study the influence of the corrosion of reinforcement bars on the mechanical behaviour of the beam (considering that the prestress effect is negligible). In the PC configuration the tendons are located in the concrete zone in tension and contributes to the mechanical strength during these tests.

Bending tests have been performed on non-centered prestress (Type 4, 6 and 9 according to (Vie, 2006). 


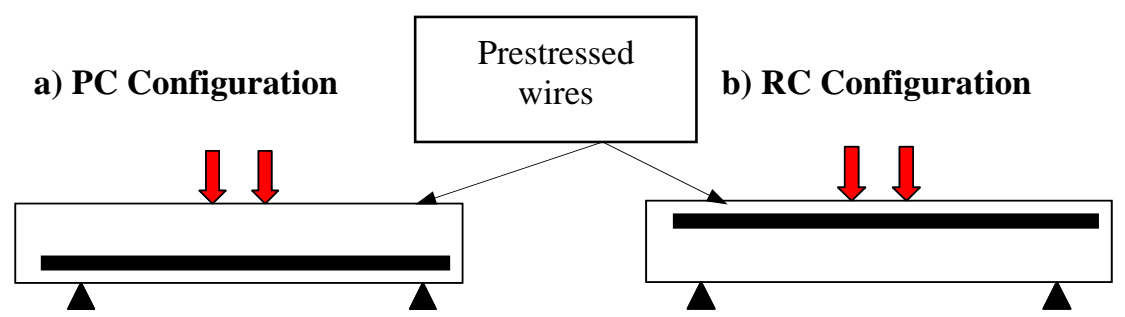

Figure 3. Configurations of the bending test

The mechanical assessment of prestressed or reinforced concrete structures is often focused on bending behaviour. Few references are available in the literature on the behaviour of such structural components in direct tensile test configuration. One of the objectives of this project is to fill this gap and to provide such data that are essential for a better knowledge of cracking. For experimental facilities, tensile tests have been performed on beams with centered tendons (type 1 and 2).

Moreover mechanical tests have been performed under monotonic and cyclic loadings. The comparison between model simulations and experimental results was limited to the global mechanical behaviour (load/mid-span deflection for 4-point bending tests and load/axial displacement for tensile tests).

\section{Partners}

Table 3. List of modelling partners

\begin{tabular}{|c|c|c|c|}
\hline partners & Type of Modeling & Institute / Company & Reference \\
\hline LM2S & 2D FEM & Commissariat à l'Energie Atomique & $\begin{array}{c}\text { (A.Millard } \\
\text { 2006) }\end{array}$ \\
\hline Oxand & 2D and 3D FEM & Oxand S.A. & (B. Capra 2006) \\
\hline LMDC & 1D FEM & $\begin{array}{c}\text { Laboratoire Matériaux et Durabilité } \\
\text { des Constructions, Toulouse }\end{array}$ & $\begin{array}{c}\text { (Ngoc-Anh Vu } \\
\text { 2006) }\end{array}$ \\
\hline IETcC & $\begin{array}{c}\text { Analytical Basic } \\
\text { design approach }\end{array}$ & $\begin{array}{c}\text { Instituto de Ciencias de la } \\
\text { Construccion Eduardo Torroja, } \\
\text { Espagne }\end{array}$ & (M.Prieto 2006) \\
\hline LMT & Multifiber FEM & $\begin{array}{c}\text { Laboratoire de Mécanqiue et } \\
\text { Technologies, ENS Cachan }\end{array}$ & $\begin{array}{c}\text { (Q.T.Nguyen } \\
\text { 2006) }\end{array}$ \\
\hline LML & $\begin{array}{c}\text { Multi layer } \\
\text { homogenisation FEM }\end{array}$ & $\begin{array}{c}\text { Institut de Recherche en Génie Civil } \\
\text { et Mécanique, Nantes }\end{array}$ & $\begin{array}{c}\text { (P. Turcry 2006) } \\
\text { approach }\end{array}$ \\
\hline LCPC & $\begin{array}{c}\text { Moment-curvature } \\
\text { analysis with } \\
\text { Probabilistic approach }\end{array}$ & $\begin{array}{c}\text { Laboratoire de Mécanique de Lille } \\
\text { (A.L. Thang } \\
\text { 2006) }\end{array}$ \\
\hline
\end{tabular}

FEM : Finite Element Model 
Eight partners have participated to the numerical simulations (Table3). The details for each test calculated by each partner are listed in Table 4 .

Table 4. Details of tests performed by each partner

\begin{tabular}{|c|c|c|c|c|c|c|c|c|c|c|}
\hline & \multirow{2}{*}{\multicolumn{4}{|c|}{ Tensile test }} & \multicolumn{6}{|c|}{ 4-point bending test } \\
\hline & & & & & \multicolumn{3}{|c|}{ RC configuration } & \multicolumn{3}{|c|}{ PC configuration } \\
\hline & 121 & 122(c) & 211(c) & 212 & 412(c) & 611(c) & 621 & 421(c) & 622(c) & 911 \\
\hline LM2S & & & & & C & C & & & & \\
\hline \multicolumn{11}{|l|}{ Oxand } \\
\hline LMDC & & C & C & & C & C & & C & C & \\
\hline \multicolumn{11}{|l|}{ IETcc } \\
\hline LMT & & & & & & C & & & C & \\
\hline \multicolumn{11}{|l|}{ GéM } \\
\hline \multicolumn{11}{|l|}{ LML } \\
\hline LCPC & & & & & & & & & & \\
\hline
\end{tabular}

\section{Description of the simulation models}

Table 5 provides information related to the numerical models used for simulations. The theoretical model approach, the concrete and the steel models and corrosion introduction are listed.

Table 5. Information about models

\begin{tabular}{|c|c|c|c|c|c|c|}
\hline Lab. & Approach & $\begin{array}{c}\text { Concrete } \\
\text { constitutive law }\end{array}$ & $\begin{array}{c}\text { R-C Steel } \\
\text { constitutive law }\end{array}$ & $\begin{array}{l}\text { Concrete- } \\
\text { steel bond }\end{array}$ & $\begin{array}{c}\begin{array}{c}\text { Corrosion effect } \\
\text { on steel } \\
\text { behaviour }\end{array} \\
\end{array}$ & Model \\
\hline LM2S & $\begin{array}{c}\text { Damage } \\
\text { mechannics }\end{array}$ & $\begin{array}{c}\text { Non linear } \\
\text { constitutive law } \\
\text { (Mazars 1984) }\end{array}$ & $\begin{array}{c}\text { Elasto plastic } \\
\text { diagram with } \\
\text { strain } \\
\text { hardening } \\
\end{array}$ & $\begin{array}{c}\text { Coulomb } \\
\text { law }\end{array}$ & $\begin{array}{l}\text { Cross section } \\
\text { loss, ductility }\end{array}$ & $\begin{array}{c}\mathrm{FE} \\
(\mathrm{CAST} 3 \mathrm{M})\end{array}$ \\
\hline \multirow[b]{2}{*}{ Oxand } & $\begin{array}{c}\text { Local isotropic } \\
\text { damage } \\
\text { mechanics } \\
\end{array}$ & Elastic damage & $\begin{array}{c}\text { Elasto } \\
\text { perfectly } \\
\text { plastic diagram } \\
\end{array}$ & Perfect & $\begin{array}{c}\text { Cross-section } \\
\text { loss }\end{array}$ & $\begin{array}{c}\mathrm{FE} \\
(\mathrm{CAST} 3 \mathrm{M})\end{array}$ \\
\hline & $\begin{array}{c}\text { Non local } \\
\text { orthotropic } \\
\text { damage } \\
\text { mechanics } \\
\end{array}$ & $\begin{array}{c}\text { Non linear } \\
\text { constitutive law }\end{array}$ & $\begin{array}{c}\text { Elasto plastic } \\
\text { diagram with } \\
\text { strain } \\
\text { hardening } \\
\end{array}$ & Perfect & $\begin{array}{c}\text { Cross-section } \\
\text { loss }\end{array}$ & $\begin{array}{c}\text { FE } \\
\text { (ATENA) }\end{array}$ \\
\hline LMDC & $\begin{array}{c}\text { Local transfer } \\
\text { of strain and } \\
\text { Strength of } \\
\text { materials }\end{array}$ & $\begin{array}{c}\text { Non linear } \\
\text { constitutive law }\end{array}$ & $\begin{array}{c}\text { Elasto } \\
\text { perfectly } \\
\text { plastic diagram }\end{array}$ & $\begin{array}{c}\text { Perfect } \\
\text { (without } \\
\text { corrosion) }\end{array}$ & $\begin{array}{l}\text { Cross-section } \\
\text { loss and bond }\end{array}$ & $\begin{array}{c}\text { FE } \\
\text { (macro- } \\
\text { élément) }\end{array}$ \\
\hline IETcc & $\begin{array}{c}\text { Basic-design } \\
\text { ULS } \\
\text { calculation }\end{array}$ & $\begin{array}{c}\text { Parabole- } \\
\text { rectangle stress- } \\
\text { strain diagram }\end{array}$ & $\begin{array}{c}\text { elasto plastic } \\
\text { diagram with } \\
\text { strain }\end{array}$ & $\begin{array}{l}\text { Not taken } \\
\text { into } \\
\text { account }\end{array}$ & $\begin{array}{c}\text { Cross-section } \\
\text { loss }\end{array}$ & Analytical \\
\hline
\end{tabular}




\begin{tabular}{|c|c|c|c|c|c|c|}
\hline & & $\begin{array}{c}\text { splitting of } \\
\text { concrete cover }\end{array}$ & hardening & & & \\
\hline LMT & $\begin{array}{c}\text { multifiber } \\
\text { approach and } \\
\text { damage } \\
\text { mechanics } \\
\end{array}$ & $\begin{array}{l}\text { Non linear } \\
\text { constitutive law } \\
\text { with cyclic } \\
\text { damage }\end{array}$ & $\begin{array}{c}\text { Elasto plastic } \\
\text { diagram with } \\
\text { strain } \\
\text { hardening and } \\
\text { softening } \\
\end{array}$ & $\begin{array}{l}\text { Not taken } \\
\text { into } \\
\text { account }\end{array}$ & $\begin{array}{l}\text { Cross section } \\
\text { loss, ductility }\end{array}$ & FE \\
\hline GéM & $\begin{array}{c}\text { Damage } \\
\text { mechanics } \\
\text { Multi layer } \\
\text { homogenisati } \\
\text { on } \\
\end{array}$ & $\begin{array}{c}\text { Non linear } \\
\text { constitutive law } \\
\text { with damage }\end{array}$ & $\begin{array}{c}\text { Elasto plastic } \\
\text { diagram with } \\
\text { strain } \\
\text { hardening }\end{array}$ & $\begin{array}{c}\text { Tri linear } \\
\text { constitutiv } \\
\text { e law }\end{array}$ & $\begin{array}{c}\text { Cross-section } \\
\text { loss }\end{array}$ & $\begin{array}{c}\text { FE } \\
\text { (Eficos) }\end{array}$ \\
\hline LML & $\begin{array}{l}\text { Moment- } \\
\text { curvature } \\
\text { analysis }\end{array}$ & $\begin{array}{l}\text { Non linear in } \\
\text { compression with } \\
\text { splitting of } \\
\text { concrete, CEB }\end{array}$ & $\begin{array}{c}\text { Elasto-plastic } \\
\text { diagram with } \\
\text { Hardening }\end{array}$ & $\begin{array}{c}\text { Non linear } \\
\text { constitutiv } \\
\text { e law }\end{array}$ & $\begin{array}{l}\text { Cross-section } \\
\text { loss and bond }\end{array}$ & $\begin{array}{c}\text { step by step } \\
\text { analysis }\end{array}$ \\
\hline LCPC & $\begin{array}{l}\text { Moment- } \\
\text { curvature } \\
\text { analysis }\end{array}$ & $\begin{array}{c}\text { Non linear } \\
\text { constitutive law } \\
\text { (Neville, 1996) } \\
\text { (Collins, 1987) }\end{array}$ & $\begin{array}{l}\text { Elasto- } \\
\text { perfectly } \\
\text { plastic } \\
\text { diagram } \\
\end{array}$ & - & $\begin{array}{c}\text { Cross-section } \\
\text { loss }\end{array}$ & $\begin{array}{c}\text { Iterative } \\
\text { Probabilistic } \\
\text { approach } \\
\text { (Monte Carlo) }\end{array}$ \\
\hline
\end{tabular}

\section{Input data}

The geometry and the tests instrumentations have been described in a previous paper (Vié, 2006). The other parameters given to the participants as input data for their numerical simulation are listed below. Some of the participants decided to modify parameters to improve their results or to take into account their own experiences.

Participants have freely adopted the loading conditions.

Tables 6 and 7 present the mechanical properties of the constitutive materials (respectively for steel and concrete) which have been measured.

Table 6. Mechanical properties of steels

\begin{tabular}{cccc}
\hline Steel type & $\begin{array}{c}\text { Yield stress } \\
\text { (MPa) }\end{array}$ & $\begin{array}{c}\text { Ultimate stress } \\
\text { (MPa) }\end{array}$ & $\begin{array}{c}\text { Young modulus } \\
\text { (GPa) }\end{array}$ \\
\hline Passive steel & $309 \pm 4$ & $399 \pm 17$ & $195 \pm 1.5$ \\
\hline Prestressing steel & $1304 \pm 2$ & $1394 \pm 21$ & $187 \pm 5.4$ \\
\hline
\end{tabular}

Table 7. Mechanical properties of 4 concrete types

\begin{tabular}{lcccc}
\hline & \multicolumn{4}{c}{ Concrete mix } \\
\cline { 2 - 5 } & $\mathbf{1 . 1}$ & $\mathbf{1 . 2}$ & $\mathbf{2 . 1}$ & $\mathbf{2 . 2}$ \\
\hline Compressive stress (MPa) & 49.1 & 68.1 & 42.9 & 47.5 \\
\hline Tensile stress (MPa) & 3.5 & 4.3 & 4.0 & 3.4 \\
\hline Young modulus (GPa) & 34.7 & 38.6 & 30.5 & 33.1 \\
\hline
\end{tabular}


Experimental measurements on two beams were performed (based on the principle of the "stress release " measurements) to evaluate the residual prestress strength within beams. According to these results, it was decided to consider a loss of about $38 \%$ on the initial prestress strength. Table 8 presents the residual prestress values used in the simulations.

Table 8. Residual prestress strength

\begin{tabular}{ccccc}
\hline Beam & $\begin{array}{c}\text { Tendon stress } \\
\text { (GPa) }\end{array}$ & $\begin{array}{c}\text { Number of } \\
\text { tendons }\end{array}$ & $\begin{array}{c}\text { Initial prestress } \\
\text { strength (kN) }\end{array}$ & $\begin{array}{c}\text { Residual prestress } \\
\text { strength (kN) }\end{array}$ \\
\hline 121 & 1.3 & 1 & 48.9 & 30.4 \\
122 & 1.3 & 1 & 50.0 & 31.1 \\
211 & 1.3 & 1 & 49.7 & 30.9 \\
212 & 1.1 & 2 & 86.2 & 53.6 \\
\hline 412 & 1.3 & 2 & 96.2 & 59.8 \\
421 & 1.2 & 2 & 95.4 & 59.4 \\
\hline 611 & 1.3 & 2 & 99.3 & 61.8 \\
621 & 1.2 & 2 & 95.4 & 59.4 \\
622 & 1.2 & 2 & 92.4 & 57.4 \\
\hline 911 & 1.3 & 4 & 198.6 & 123.5 \\
\hline
\end{tabular}

For beam 211 the simulations are performed by considering only 1 tendon (and not 2 as initially proposed). After completion of the mechanical measurements and destruction of the concrete cover, the visual inspection of the anchorage device shows a complete slackening for one tendon. Consequently we can think that during mechanical test on this beam, only one tendon was really acting. Experimental results confirm this observation.

Two beams for tensile tests and four beams for 4-points bending tests have been tested under cyclic loading. For the $\mathrm{k}^{\text {th }}$ cycle, datas that have been provided for simulations are : (i) the initial load, (ii) the maximal deflection at maximal stress, and (iii) the final load at the end of the cycle.

A practical aspect concerning tensile tests results must be noticed for numerical simulations. When the beam was placed on the tensile test device, an eccentricity of the loading condition was observed that not leads to perform a pure tensile test but a bending moment was applied. The following information have been given to the participants to be taken into account in the numerical simulations : two eccentricity parameters (in orthogonal directions) were evaluated from experimental results given by gauges fixed on the beams during tensile tests (Vie, 2006). They are given in table 9. 
Table 9. Eccentricity values for the 4 beams tested in tensile configuration

\begin{tabular}{ccc}
\hline Beam & $\begin{array}{c}\text { Eccentricity in the first } \\
\text { direction }\end{array}$ & $\begin{array}{c}\text { Eccentricity in the } \\
\text { second direction }\end{array}$ \\
\hline 121 & $\mathrm{e}_{1}=38.7 \mathrm{~mm}$ & $\mathrm{e}_{2}=28.5 \mathrm{~mm}$ \\
122 & $\mathrm{e}_{1}=-25 \mathrm{~mm}$ & $\mathrm{e}_{2}=3 \mathrm{~mm}$ \\
211 & $\mathrm{e}_{1}=-1 ., 8 \mathrm{~mm}$ & $\mathrm{e}_{2}=-4.8 \mathrm{~mm}$ \\
212 & $\mathrm{e}_{1}=-21.9 \mathrm{~mm}$ & $\mathrm{e}_{2}=31.3 \mathrm{~mm}$ \\
\hline
\end{tabular}

After completion of the mechanical tests, concrete cover was removed to examine visually the local corrosion of steel rebars along the beam. Diameter loss is evaluated for each passive steel located at the 4 beam sides . Figure 4 illustrates examples of corrosion distribution for beam 212 (tensile test) and for beam 421 (4points bending test).

Data related to the real corrosion condition of the passive steels was also provided. The distributions of the corrosion for all the rebars of all the beams were communicated in order to be used in the simulations.
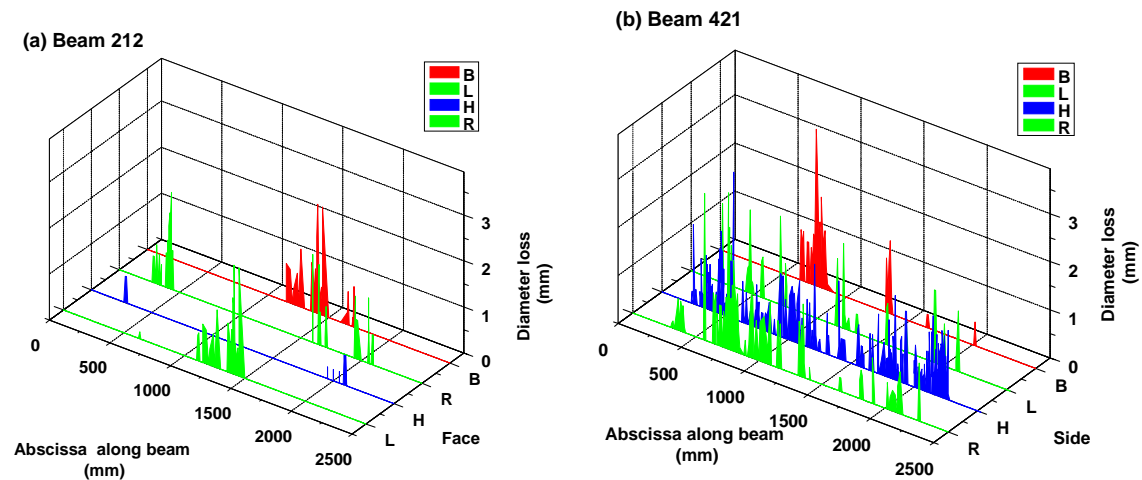

Figure 4. Corrosion Distribution on passive steel (for each side) along beam - (a) beam 212 (b) beam 421.

\section{Results - Examples of comparison between experimental and numerical results}

The comparison between numerical and experimental results will be limited in this paper to the global mechanical behaviour. The experimental load-displacement curves and the computed load-displacement curves are exposed in annex of this paper for all that have been tested. 


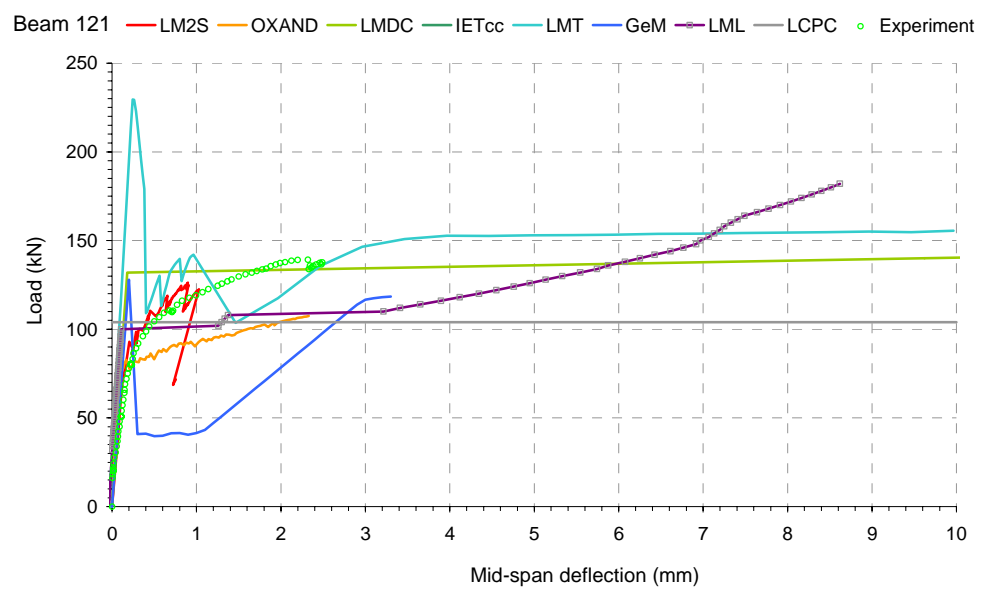

Figure 5. Example of the Force - Displacement curve for monotonic tensile test beam 121 - experimental and numerical results.

Figure 6 presents the synthesis of the ultimate load for the 4 beams tested in this configuration (tensile test) and assessed from simulations and experimental results.

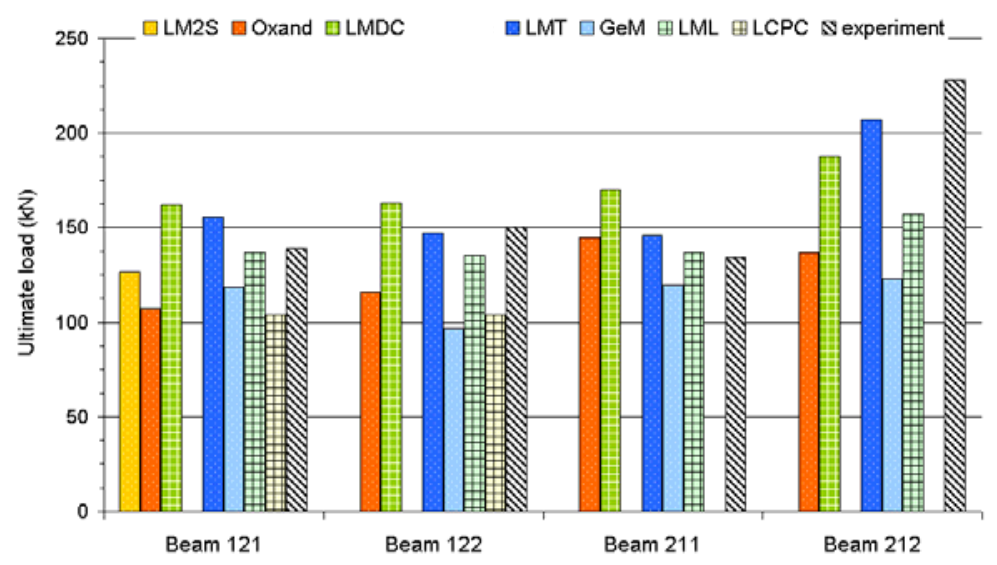

Figure 6. Synthesis of ultimate loads for direct tensile tests - simulations and experimental results - 
Figure 7 presents an example of the load-mid span deflection curves for beam 621 tested in RC configuration (monotonic test). On the same plots experimental and simulation results are drawn.

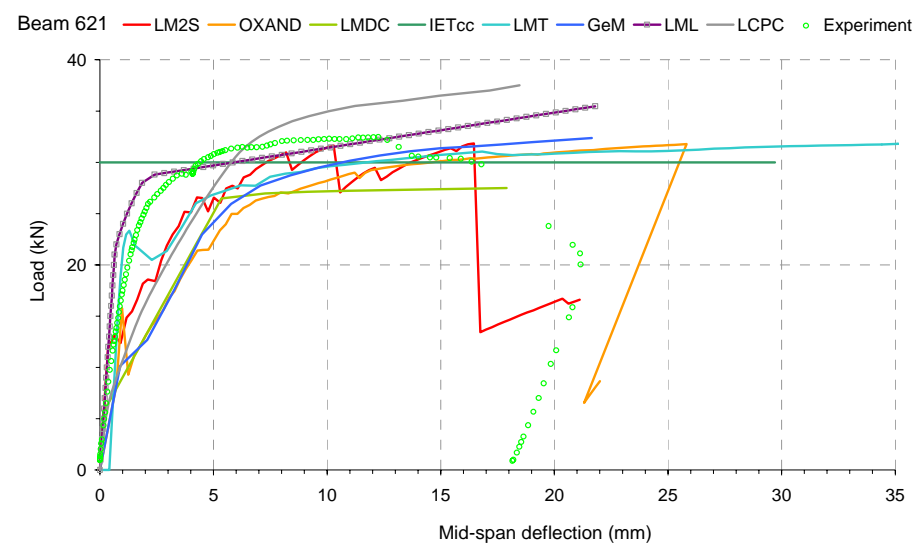

Figure 7. Force - Deflection for the 4-points monotonic bending test (Reinforced Concrete (RC) configuration) - beam 621.

Figure 8 presents the load-mid span deflection curves for beam 622 tested in PC configuration (cyclic test). On the same plots, the experimental and simulation results are given.

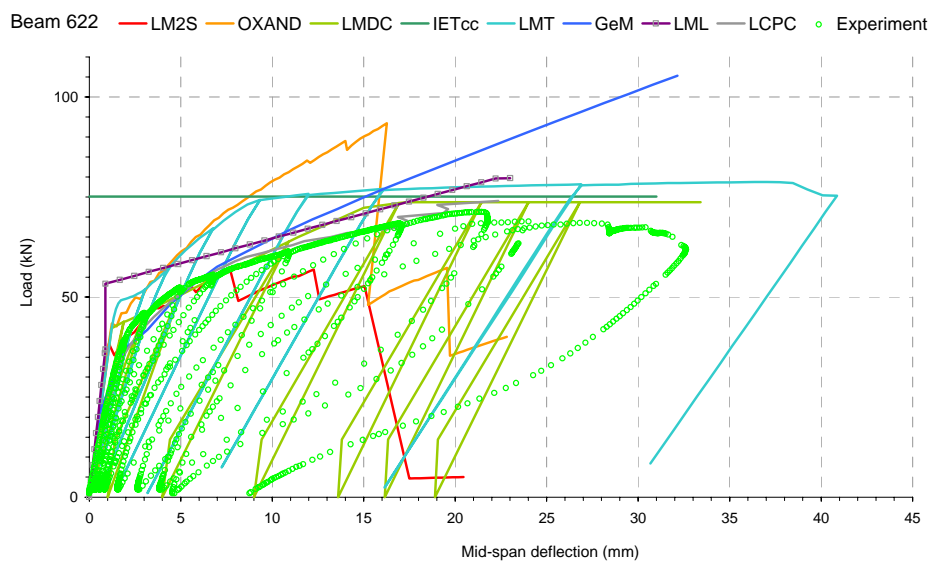

Figure 8. Force - Deflection for the 4-points bending cyclic test (Prestressed Concrete (PC) configuration) - beam 622. 
Figure 9 presents a synthesis of the ultimate load for the 6 beams tested in 4-points bending configurations and assessed from simulations and experimental data.

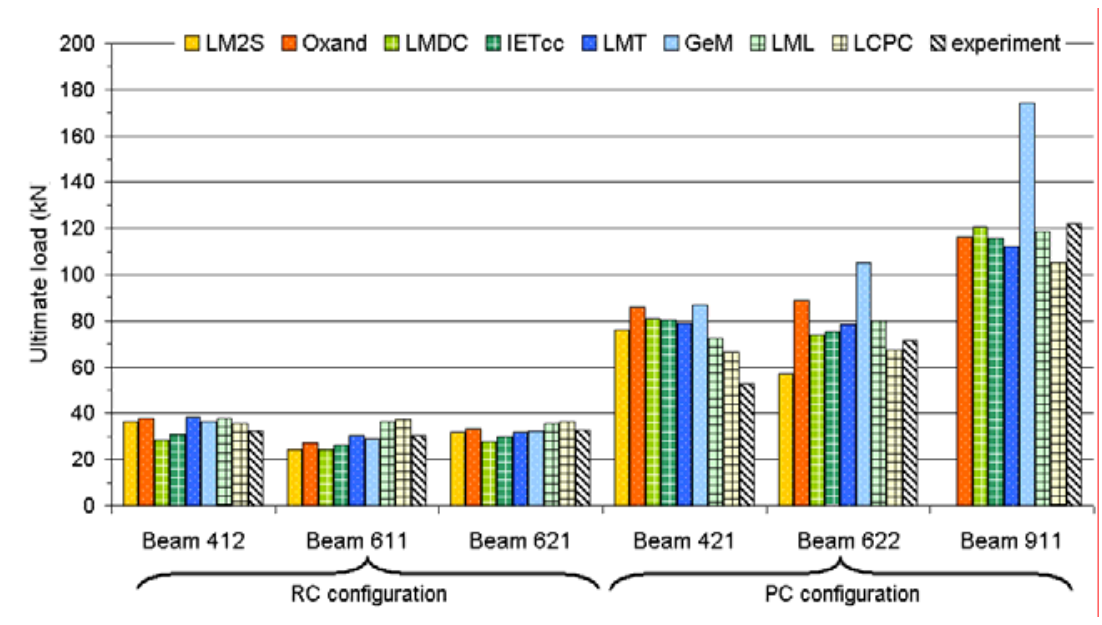

Figure 9. Synthesis of ultimate loads for the 4-points bending tests - simulations and experimental results.

\section{Analysis of the results}

\subsection{Precision of the simulations}

Several indicators are defined in order to quantify the differences between the numerical simulations and the experimental results :

- The load for elastic theoretical deflection (estimated around $4 \mathrm{~mm}$ ).

- The load at $\mathbf{0 . 5 \%}$ of the steel plastic strain corresponds to an intermediate strain between the ultimate strain (1\% according to French code BAEL 91) and the elastic strain $(0.15 \%$ from the measurements results [Vié, 2006] $0.5 \%$ is also 3 times the elastic strain of the rebar. To calculate the equivalent deflection, the beam theory was used and the concrete strain has been neglected. The equivalent deflection of $0.5 \%$ of rebar strain is around $12 \mathrm{~mm}$.

- The Ultimate Load is the force $(\mathrm{kN})$ corresponding to the failure of the tested element. This indicator corresponds to an ultimate limit state. The first three indicators are used to measure the closeness between numerical and experimental behaviour of the beams 
- The Energy to Failure is the energy required to reach the ultimate load. It corresponds to the area under the load - deflection curve until failure (Figures 5, 7 and 8).

- The 60\% Energy to failure corresponds to the area under the load deflection curve until the force reaches $60 \%$ of the ultimate load. Roughly, this corresponds to the end of the elastic behaviour and the starting yielding stage. This indicator should account for a service limit state.

- $\quad$ The Initial Rigidity is the initial slope of the load - deflection curve. It corresponds to the linear elastic behaviour of the element, before any cracking.

All the partners have identified for their own numerical simulations the ultimate load, the initial rigidity, and the energies then the relative differences has been calculated by :

$$
\varepsilon_{\text {rel }}=\frac{\mid \text { measured.value }- \text { simulation.result } \mid}{\text { measured.value }}
$$

These relative differences was estimated for each model, for each parameter, for each test specimen. . Table 10 present the mean value of these parameters.

The data in table 10 indicates that the failure load is the best estimated indicator by all the models. The relative error ranges from $-8 \%$ to $1 \%$, which is a good result. However, for all models, the standard deviation is quite important (from 17 $\%$ to $36 \%)$.

For the initial stiffness, the dispersion of the results, among the models, has to be highlighted. Each numerical simulation has used the same input data for the elastic modulus of the concrete and the steel and the models are supposed to behave identically in the elastic phase. A clear explanation has not been yet found. Probably, small differences in the modelling formulation or in boundary conditions and the geometry can lead to significant differences in the initial stiffness. The large dispersion may explain the large mean value of the relative error.

There are also differences between the stiffness of the numerical simulations and the stiffness of experimental results. An explanation could be found in the initial cracking pattern which is not taken into account by the numerical models.

The simulations look more accurate for large loading conditions (close to failure) than for low loadings. This is coherent with the fact that the error for the energy to failure is lower than the error for the $60 \%$ failure energy. Dispersion is still large, as indicated by the standard deviation values (Table 10). Moreover, it is difficult to reproduce the behaviour for low loadings because the tensile cracks of the concrete determine the behaviour of the beams. At the ultimate value, steels control the tensile behaviour with the compression of concrete which is easier to consider. For these reasons no interpretation based on the energy values can be drawn. 
Table 10. Relative error of modelling with respect to experimental results. The statistical analysis is done on the available test specimens

\begin{tabular}{|c|c|c|c|c|c|c|c|c|}
\hline & \multicolumn{2}{|l|}{ Ultimate Load } & \multicolumn{2}{c|}{$\begin{array}{c}\text { Energy to } \\
\text { Failure }\end{array}$} & $\begin{array}{c}\text { Energy at 60\% } \\
\text { of the failure } \\
\text { load }\end{array}$ & \multicolumn{2}{l|}{ Initial Rigidity } \\
\hline & Average & $\begin{array}{c}\text { St } \\
\text { Dev. }\end{array}$ & Average & $\begin{array}{c}\text { St } \\
\text { Dev. }\end{array}$ & Average & $\begin{array}{c}\text { St } \\
\text { Dev. }\end{array}$ & Average & $\begin{array}{c}\text { St } \\
\text { Dev. }\end{array}$ \\
\hline CEA-LM2S & $-1 \%$ & $25 \%$ & $27 \%$ & $43 \%$ & $-48 \%$ & $102 \%$ & $-79 \%$ & $20 \%$ \\
\hline Oxand & $-2 \%$ & $29 \%$ & $-8 \%$ & $58 \%$ & $-59 \%$ & $138 \%$ & $-97 \%$ & $60 \%$ \\
\hline LMDC & $-4 \%$ & $23 \%$ & $-68 \%$ & $53 \%$ & $-64 \%$ & $190 \%$ & $-81 \%$ & $57 \%$ \\
\hline IETcC & $-5 \%$ & $24 \%$ & $-110 \%$ & $32 \%$ & N/A & N/A & $-20 \%$ & $69 \%$ \\
\hline LMT & $-8 \%$ & $17 \%$ & $-36 \%$ & $131 \%$ & $37 \%$ & $21 \%$ & $-101 \%$ & $51 \%$ \\
\hline GeM & $-6 \%$ & $36 \%$ & $-19 \%$ & $58 \%$ & $-441 \%$ & $212 \%$ & $-48 \%$ & $75 \%$ \\
\hline LML & $-5 \%$ & $19 \%$ & $-58 \%$ & $53 \%$ & $34 \%$ & $50 \%$ & $-89 \%$ & $37 \%$ \\
\hline LCPC & $1 \%$ & $22 \%$ & $69 \%$ & $22 \%$ & $-82 \%$ & $181 \%$ & $-45 \%$ & $59 \%$ \\
\hline & & & & & & & & \\
\hline All models & $-4 \%$ & $24 \%$ & $-26 \%$ & $81 \%$ & $-100 \%$ & $214 \%$ & $-73 \%$ & $60 \%$ \\
\hline
\end{tabular}

The strain energy computed by each participant is strongly dependent on the strain computed at the failure. This indicator could lead to artificial discrepancy of the difference between the numerical simulation if the strain and the load can not be fixed accurately. So others indicators (table11) are proposed to explain this drawback.

An analysis for beams tested in flexion (RC or PC) has been done separately using the first three indicators. The average difference (table 11) is computed for all the results of flexion tests except for beam 421 tests because, although differences are high, they are not relevant of the quality of the numerical simulations to reproduce with good agreement the experimental results.

The average difference between the computed and the experimental behaviour can be estimated around 15\% (more or less). This value can be interpreted as the numerical precision of the models to simulated the real behaviour of the beams. 
Table 11. Relative differences between experimental and numerical results. The analysis is only done on the 4-points bending tests except for the beam 421.

\begin{tabular}{|c|c|c|c|}
\hline & Elastic load & load at 0,5\% plastic def. & Ultimate load \\
\hline CEA-LM2S & $12 \%$ & $39 \%$ & $14 \%$ \\
\hline Oxand & $23 \%$ & $22 \%$ & $12 \%$ \\
\hline LMDC & $18 \%$ & $20 \%$ & $10 \%$ \\
\hline IETcC & $26 \%$ & $9 \%$ & $7 \%$ \\
\hline LMT & $14 \%$ & $10 \%$ & $8 \%$ \\
\hline GeM & $16 \%$ & $10 \%$ & $22 \%$ \\
\hline LML & $6 \%$ & $6 \%$ & $12 \%$ \\
\hline LCPC & $11 \%$ & $11 \%$ & $13 \%$ \\
\hline All models & $16 \%$ & & $12 \%$ \\
\hline
\end{tabular}

\subsection{Relation between the model type and the simulation results}

The accuracy of the simulations depends on the model and on the interpretation of the results. In order to see if the model type has a greater influence than the human factors, it is interesting to assess if similar models provide similar results. Based on Table 1 and Table 3, the models are ranged as it follows:

- Basic design models: IETcC, LML and LCPC. The behaviour of the critical section is analysed with the principles of the theory of beam systems.

- Homogenised section models, where every cross section is homogenised either by a multifiber approach (LMT and GEM) or by the strength of materials theory (LMDC). Further, the longitudinal behaviour of the beam is evaluated by $1 \mathrm{D}$ finite elements computations.

- Complete finite element models (2D or 3D) : CEA-LM2S and Oxand

The correlation coefficients of the simulation results were computed for all the tested specimens. A priori, similar models should have high correlation coefficients. The results of this analysis do not show any clear tendency:

- The ultimate limit load results are highly correlated for the basic design models and the finite element models. But the GEM results are not correlated with LMDC and LMT.

- The initial stiffness is highly correlated for the homogenised section models and the complete finite element models. But the LML and LCPC models are not correlated with the IETcc model. 
- We can notice high correlation coefficient for models belonging to different categories. For instance the ultimate limit loads of Oxand and IETcc are highly correlated. We can observed the same characteristic for the initial stiffness of CEA-LM2S and LCPC.

Further, the correlation coefficients were calculated between the models and the experimental results. For the ultimate load, the best correlation coefficient is obtained for LMT and LCPC (0.98) and the smallest for GEM (0.71). For the initial stiffness, the highest correlation is obtained for CEA and LCPC $(0,99)$ and the smallest for IETcc $(0,71)$. We stress out that this indicates that there is no clear ranking between different types of models. Actually, given the variability of the relative error of the simulations (Table 8), any attempt to rate the models seems ineffective.

These results indicate that the model type has not a significant importance for the simulation results. Further analysis based on different criteria did not show any tendency either. So it is difficult to state which modelling approach leads to a better accuracy.

\subsection{Corrosion effect according to the models}

One important question is whether the corrosion has a significant impact on the mechanical behaviour of reinforced concrete elements. As no experimental results of the mechanical capacity of intact beams are available, a direct experimental answer to this question cannot be provided.

However the models may give an indirect answer. Complementary simulations were performed supposing the beams were intact, with no corrosion. Then the reductions of the ultimate load caused by the corrosion can be evaluated.

The corrosion distribution is not uniform along the beams and among the beams. In order to get a global indicator for the corrosion condition of each beam the average loss of steel area was computed for each beam. Among the ten beams that were tested, these "average" corrosion conditions ranges from $0.5 \%$ to $12 \%$. The figure 9 presents the results of the ultimate load reduction produced by the corrosion, according to the models.

A clear tendency can be noticed at this stage. As corrosion increases, the ultimate load decreases. For instance for an average $12 \%$ of steel section loss, the predicted ultimate load reduction varies between $12 \%$ and $34 \%$. for a $6 \%$ of steel section loss, the load reduction varies between $6 \%$ and $15 \%$. The influence of the corrosion appears to be linear $\left(\mathrm{R}^{2}\right.$ for a linear regression is 0.89 ). 


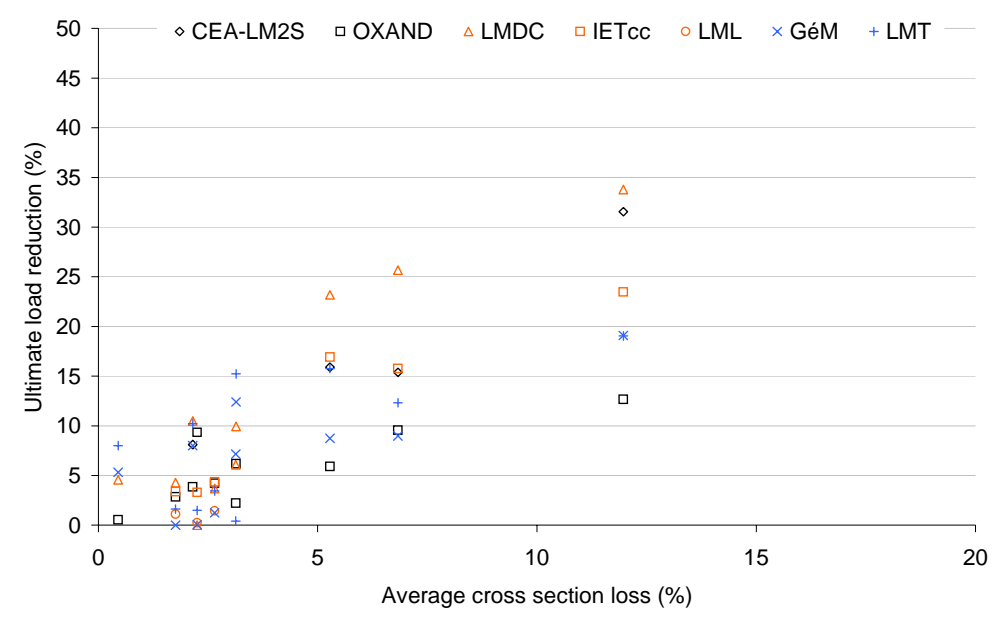

Figure 10. The simulated ultimate load reduction as a function of the average steel section loss for each beam

An interesting result is that the models considering the influence of the corrosion on several material parameters like the bond (LMDC) or the steel ductility (CEA LM2S) indicate a higher effect of the corrosion than the ones that consider that corrosion produces only a steel reduction (Oxand or GEM). This is not surprising, but given the variability of the result, this is confirmed.

The comparison between the ultimate load reduction and the dispersion of the modelling leads to assess approximately the influence of the corrosion on the simulations. It can be noted that the numerical modelling has the same influence on the ultimate load than the corrosion modelling and the scattering observed for numerical results is approximately equal to the loss of carrying load by steel corrosion.

\section{Conclusions}

The results of the benchmark project are presented in order to validate the actual mechanical models to simulate the mechanical behaviour of corroded concrete elements. Numerical simulations are compared with experimental results of tensile tests and 4 points bending tests. 8 partners (from academic and industry laboratories) have participated to the simulation program with a diversity of models ranging from finite elements to basic design models. 
This paper presents the comparison between experimental and numerical results and a critical analysis of these results. It appears that all the models may predict the behaviour of corroded specimens with an average relative error of $15 \%$. .

The models present some unexpected discrepancies, among them and with respect to the experimental results, for the simulation of the elastic behaviour of the beams. The mean and the standard deviation values of the relative error for the simulation of the initial stiffness and for the energies are very large. This variability makes a critical analysis very difficult.

No clear tendency appears with respect to the model type . It was not possible to state whether basic design models behave differently from multifiber models or 2D and 3D finite elements models.

The models reflect the ultimate load reduction produced by corrosion in a coherent manner. The influence of the corrosion degree on the mechanical capacity reduction seems to be linear. Some models account only for the steel section reduction. Others consider some additional effects as bond and ductility loss. The later produce more conservative simulation results, as expected. Taken into account the influence of loss section by the corrosion is as important as to take into account the influence of the cracking condition of the beams, to compute the ultimate load.

As a final remark, it may be concluded that the models may account for the mechanical capacity reduction produced by the corrosion. Unexpectedly, a large variability of the results was observed for the simulation of the elastic behaviour of the prestressed and reinforced concrete components. This seems to be related more to the modelling practice and less to the corrosion effects. Further investigation and research should clarify this aspect.

\section{Acknowledgments}

The authors acknowledge the financial support of the French Ministry of National Education, Research and Technology. The study is labelled by RGCU (Urban and Civil Engineering Network), which is gratefully acknowledged. The authors wish to express their gratitude to all the participants for providing their results and for participating in meetings where stimulating discussions took place.

\section{References}

Capra B. et al. Simulation par éléments finis du comportement mécanique de corps d'épreuve en béton armé et précontraint près vieillissement en milieux marin. Revue européenne de génie civil décembre-2006 
Castel A. et al., "Mechanical behavior of corroded reinforced concrete beams: Part 1 . Experimental study of corroded beams”; Materials and Structures, vol.33, 2000, pp. 539544.

Collins M.P., Mitchell D., Prestressed concrete basics, Canadian Prestressed Concrete Institute, Ottawa, Canada, 1987

Crermona C. Houde M.J; Modélisation déterministe et probabiliste duu comportement mécanique simplifié du corps d'épreuve. Revue européenne de génie civil décembre2006

Dekoster M. et al., "Modelling of the flexural behaviour of RC beams subjected to localised and uniform corrosion”; Engineering Structures, vol.25, n¹0, 2003, pp. 1333-1341.

Ghavamian S. et al., "Discussions over MECA project results", Revue française de génie civil, vol. 7, n 5, 2003, pp. 543-581.

Millard A. Vivier M. Modélisations bidimensionnelles Revue européenne de génie civil décembre-2006

Montemor M.F. et al., "Chloride-induced corrosion on reinforcing steel: from the fundamentals to the monitoring techniques", Cement and Concrete Composites, vol.25, 2003, pp. 491-502.

Neville A., "Chloride attack of reinforced concrete: an overview"; ACI Materials and Structures, vol.28, 1995, pp. 63-70.

Neville M., Propriétés des bétons, Editions Eyrolles, 1996

Nguyen Q.T. Raueneau F. Berthaud Y. Modélisation de structures corrodées par une approche multifibre Revue européenne de génie civil décembre-2006

Poupard O. et al., "Benchmark des poutres de la Rance: Damage diagnosis of reinforced concrete beams after 40 years exposure in marine environment”, in proceedings of EuroCorr05, Sept. 2005, Lisbon.

Prieto M Munoz A Andrade C. Tanner P. Elastoplastic model for beams damaged by corrosion Revue européenne de génie civil décembre-2006

Rodriguez J. et al., "Load carrying capacity of concrete structures with corroded reinforcement”; Construction Building Materials, vol.11, 1997, p. 239-248.

Turcry P. Bonnet S. Pijaudier-Cabot G. Influence de la corrosion sur le comportement mécanique de poutres attaquées par la corrosion: utilisation du code de calcul eficos Revue européenne de génie civil décembre-2006

Thang A.L. Maurel O. Buyle -Bodin F. Numerical evaluation of structural behaviour of prestressed concrete beams damaged by corrosion Revue européenne de génie civil décembre-2006

Tuutti K., Corrosion of steel in concrete, in: CBI Research Report $n^{\circ} 4.82$, Swedish Cement and Concrete Research Institute, Stockholm, Sweden (1982).

Vié D. et al., "Benchmark des poutres de la Rance - comportement mécanique de poutres corrodées - Partie expérimentale”, Revue européenne de génie civil décembre-2006 
$\mathrm{Vu}$.N.A. Castel A. François R Modélisation LMDC Revue européenne de génie civil décembre-2006

\section{Annex: Global behaviour of beams experimentally tested and calculated}

Force - Displacement curves for tensile tests
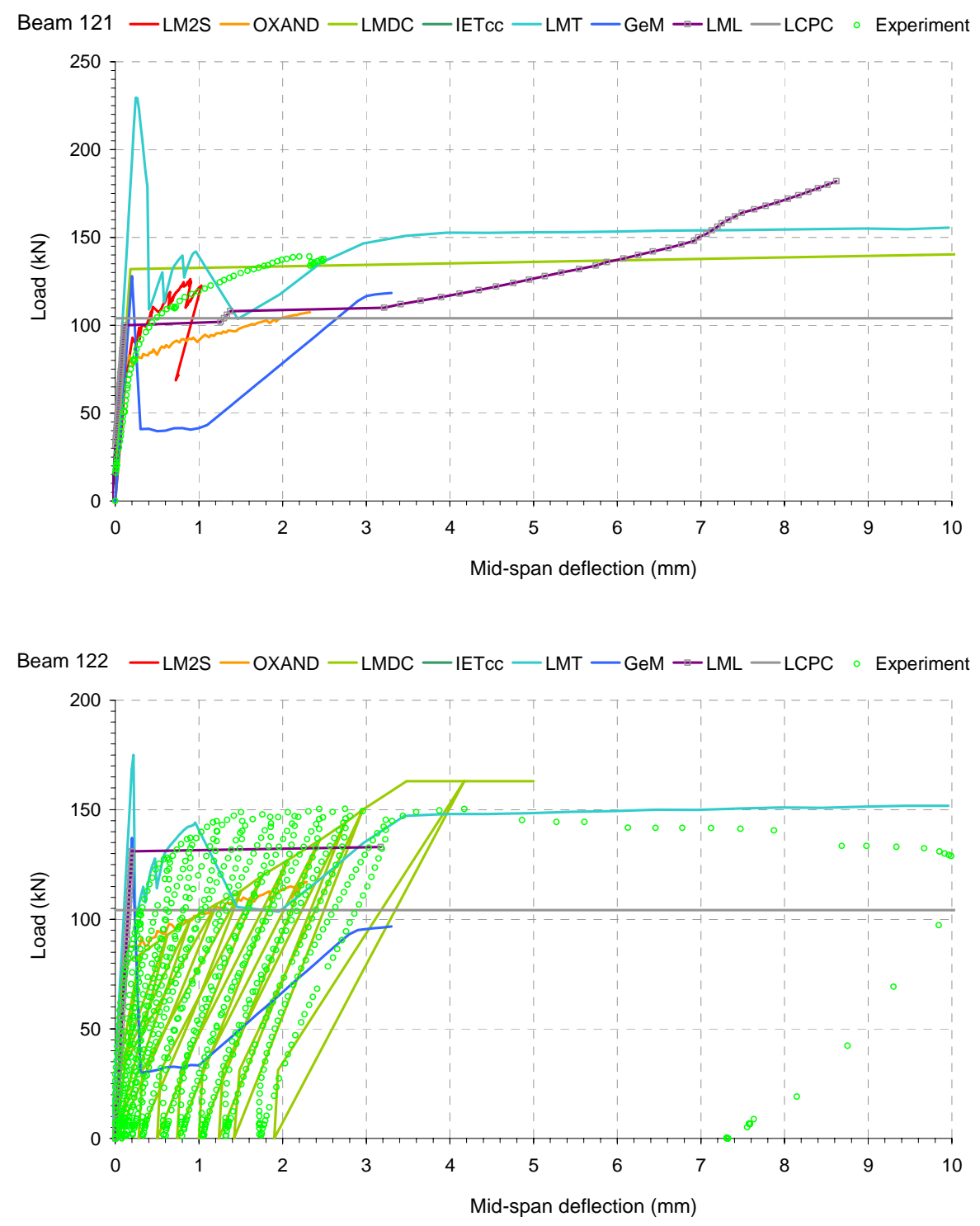

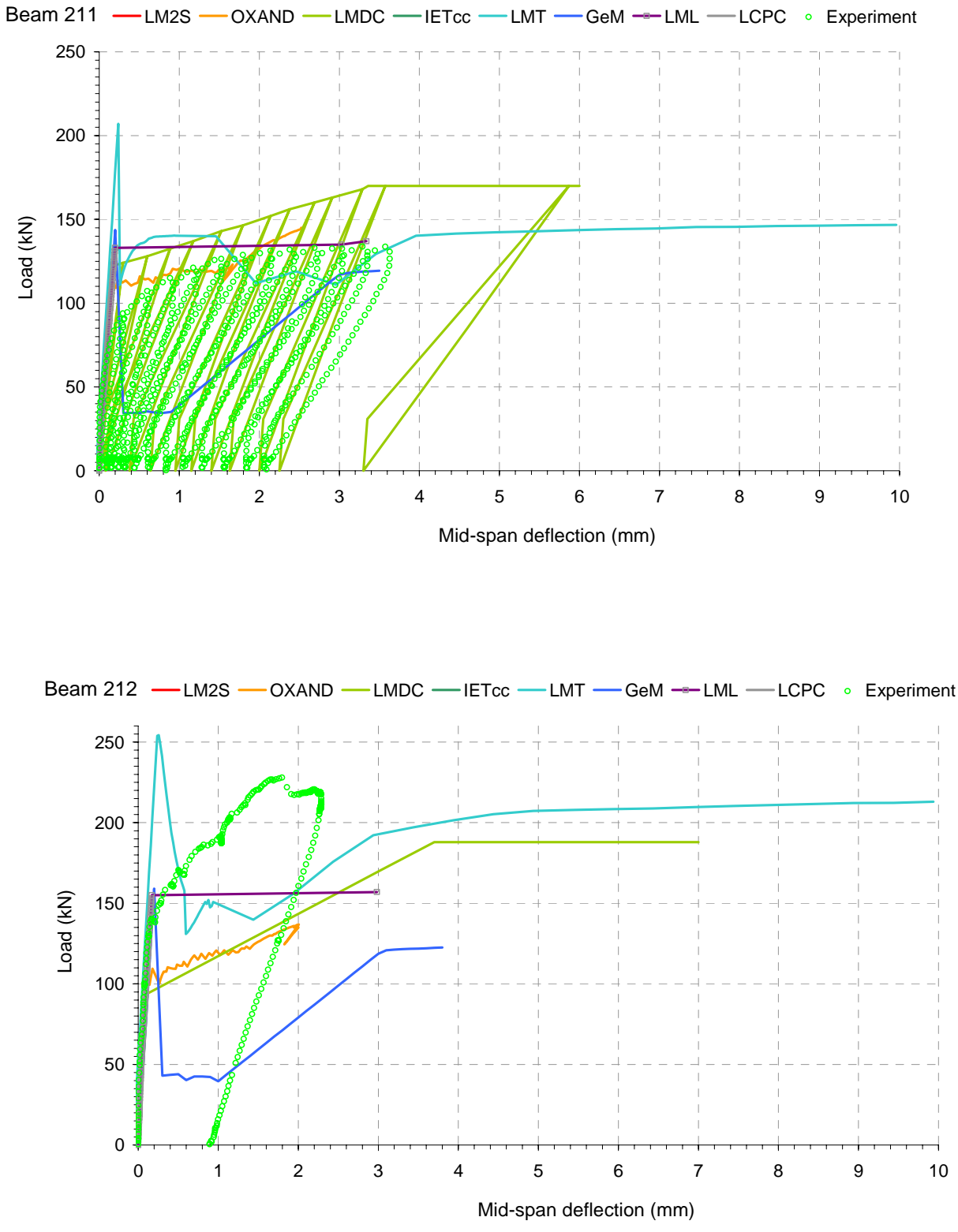
Force - Mid-span deflection for the 4-points bending tests.

RC configurations (beams 412, 611, 621)
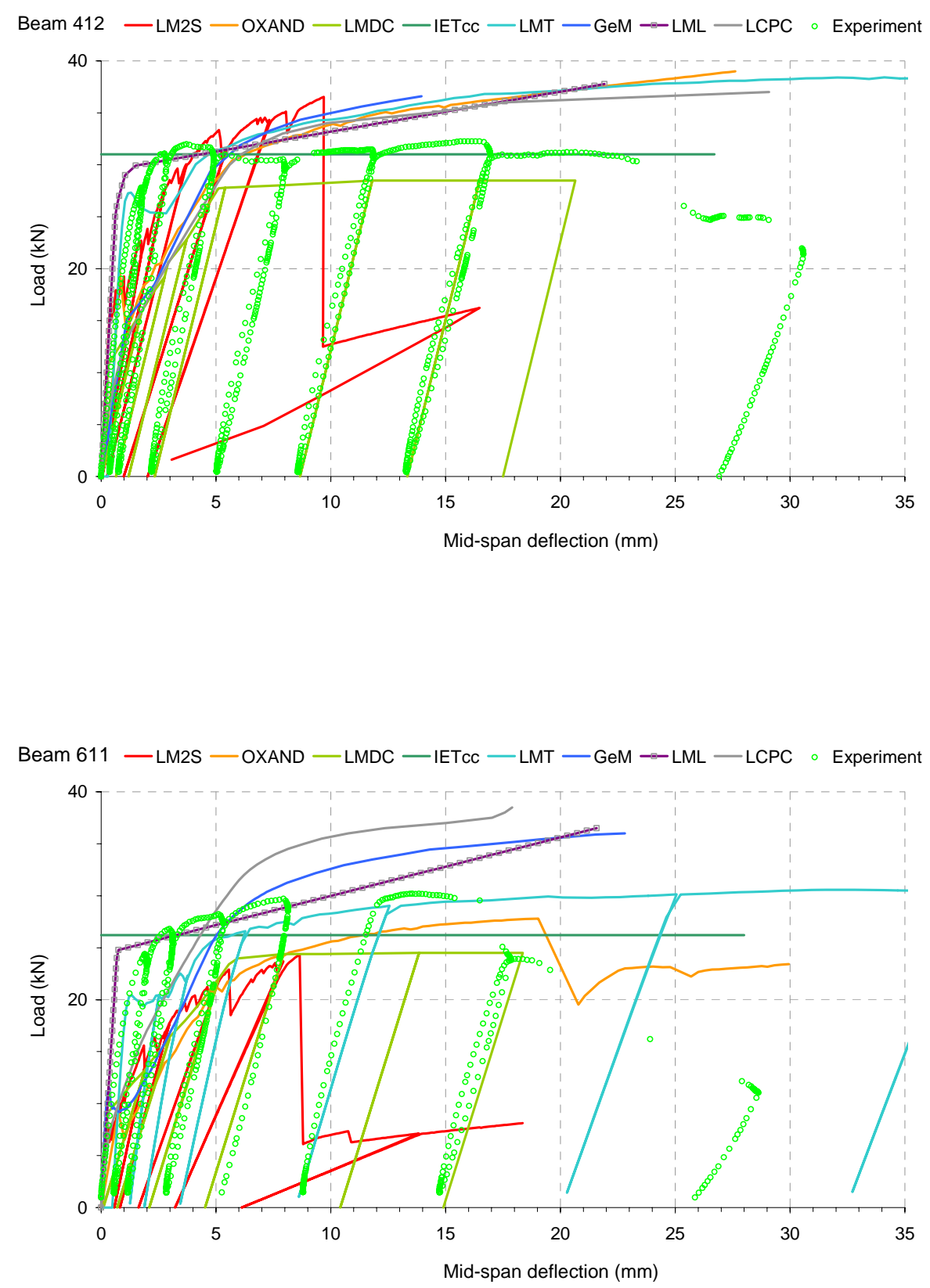


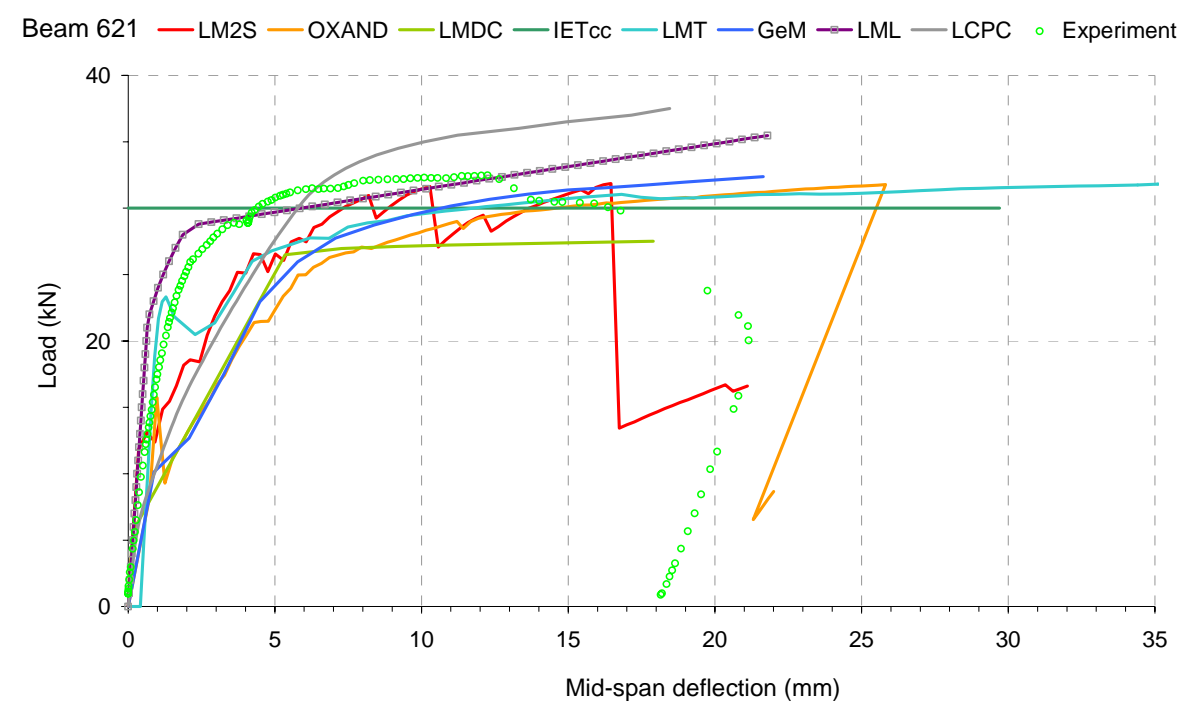

PC configurations (beams 421, 622, 911)

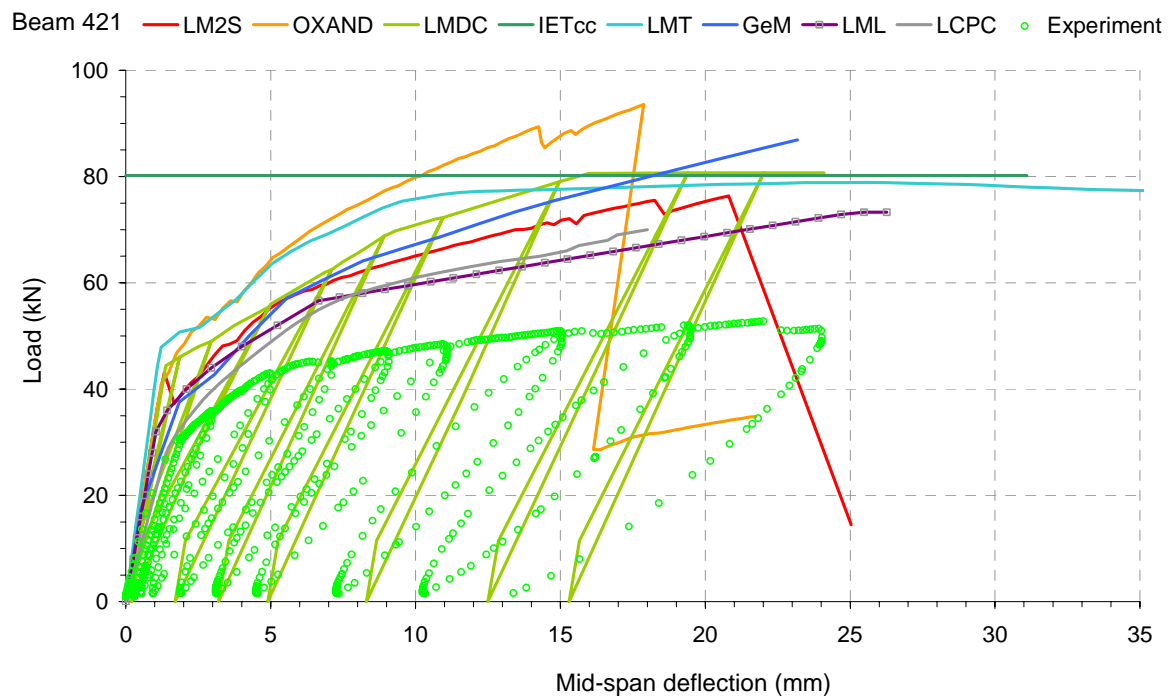



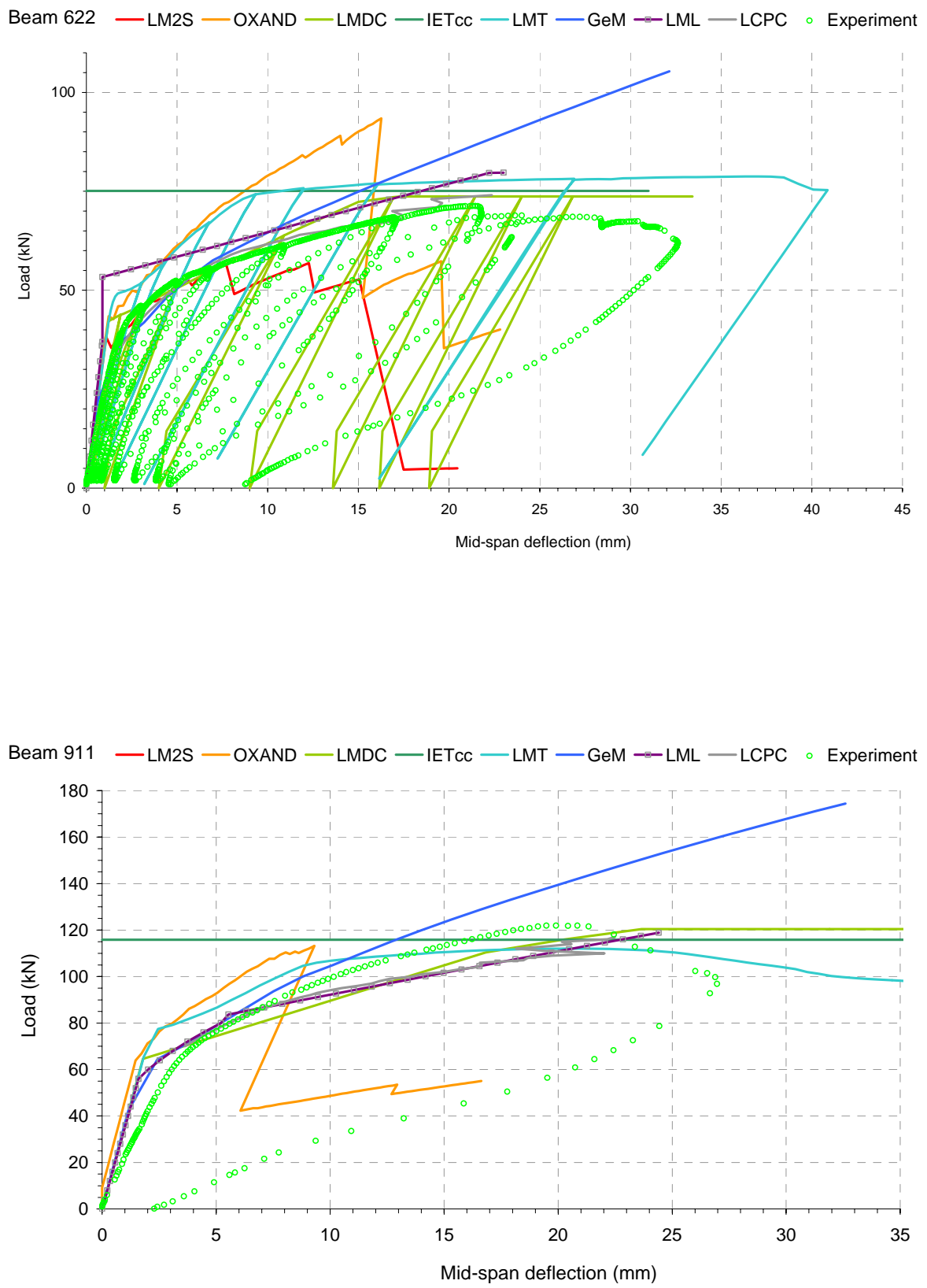